\title{
FUGA DE LA SUPREMA. LOS MORISCOS EN BÚSQUEDA DE LA BENEVOLENCIA DEL PAPA*
}

\author{
Bruno Pomara Saverino**
}

Con el presente trabajo pretendo examinar un episodio tan relevante, como poco conocido, de la historia de la relación entre Italia y los moriscos, en que se ven involucradas las Inquisiciones española y romana. Trataré de reconstruir el contexto de las fugas emprendidas por un grupo de moriscos aragoneses desde sus pueblos de origen hasta Roma. Organizados para escapar de la represión de la Suprema entre los años setenta del Quinientos hasta la expulsión, los huidos solicitan un perdón "preventivo" ante los pontífices y el Santo Oficio romano. El papel de salvaguarda e inmunidad, otorgado por el papa, les serviría a la vuelta a España: enseñándolo a los inquisidores aragoneses, los moriscos estiman no caer en las redes de sus pesquisas.

Estos individuos forman parte de un conjunto de moriscos que viajaron a Italia antes de la expulsión general. Apenas hay unos estudios que cuentan los derroteros italianos de los moriscos españoles: estos se centran, en particular, en los años posteriores a la publicación de los decretos de expulsión de $1609^{1}$. En cambio, no contamos con trabajos relativos a los movimientos de esta minoría hacia Italia antes de su destierro, salvo a referencias concretas dispersas. Se sabe que circularon unas guías de viaje en aljamiado en la segunda mitad

* Abreviaciones: TCD = Trinity College of Dublin; BL = British Library (Londres); ACDF = Archivio della Congregazione della Dottrina della Fede (Ciudad del Vaticano); BAV = Biblioteca Apostolica Vaticana; BC = Biblioteca Casanatense (Roma); AHN = Archivo Histórico Nacional; Inq. = Inquisición.

Esta investigación ha sido realizada gracias a la beca otorgada por el Centro de Estudios Mudéjares de Teruel y se enmarca dentro del proyecto Nuevas perspectivas de historia social en los territorios hispánicos del Mediterráneo Occidental en la Edad Moderna (HAR2014-53298-C2-1), dirigido por el prof. Ricardo Franch Benavent. Debo agradecer a Damián Rustarazo por la realización de los mapas.

** Universitat de València.

1. Véase en particular el número monográfico "Diaspora morisca", Quaderni storici, 144, 2013, coordinado por G. FIUME y S. PASTORE y el libro firmado por quien escribe, Rifugiati. I moriscos e l'Italia, Firenze, Firenze University Press, 2017. 
del $\mathrm{XVI}^{2}$ : estas guías orientaban a los moriscos que querían ir a Estambul atravesando el norte de Italia hasta Venecia, la ciudad que facilitaba el paso de los moriscos hacia el Imperio Otomano y por la cual transitaban también muchos espías.

Gracias a la reconstrucción de María Carmen Ansón, se conoce la trayectoria biográfica de uno de los más destacados moriscos aragoneses, Gaspar Zaydejos de Torrellas, morisco que marcó un antes y después en esa historia que relataré a continuación ${ }^{3}$. Ansón ha abordado a este personaje utilizando la correspondencia entre la inquisición aragonesa y la Suprema, relaciones de causas y documentación de fuentes locales, desde protocolos notariales hasta los registros parroquiales. Aquí, a través de la localización de nuevas fuentes, intentaré arrojar luz sobre otros aspectos de los sucesos de Gaspar Zaydejos -que arrancaron en los años 70 del siglo XVI- como punto de partida para situar todos los casos posteriores de moriscos que constan en las fuentes. El fin último del trabajo es la descripción de un fenómeno con importantes implicaciones y consecuencias, tanto en la historia de los moriscos, como en la de la Inquisición ${ }^{4}$. El marco general en el que se encuadra esta cuestión, de hecho, se puede enriquecer desde otro punto de vista, que constituye la base más voluminosa de este artículo: la documentación pontificia. Los estudios de John Tedeschi han explicado cómo se ha perdido y dispersado la documentación judicial del Santo Oficio romano ${ }^{5}$. Los poquísimos registros supérstites, relativos a sentencias y a fascículos procesales inquisitoriales producidos por esta institución, se guardan en el Trinity College de Dublín. Respecto a esta investigación, he podido contar con los registros de sentencias y abjuraciones de los años 1603, 1607 y $1608^{6}$. Por lo demás queda un gran vacío documental, que he intentado colmar cotejando los decreta del Archivo de la Congregación para la Doctrina de la Fe. En los decreta se pueden consultar los verbales de los consejos del Santo Oficio romano tocantes a las principales decisiones tomadas en sus reuniones,

2. L. López-BARALT, A. IrIZARry, “Dos itinerarios secretos de los moriscos del siglo XVI (Los manuscritos aljamiados 774 de la Biblioteca Nacional de París y T-16 de la Real Academia de la Historia)", en Homenaje a Álvaro Galmés de Fuentes, Oviedo-Madrid, Universidad de OviedoGredos, 1985, vol. 1, pp. 547-582; J. LiNCOLN, "An itinerary for moriscos refugees from 16th century Spain”, Geographical Review, CXXIX, 1939, pp. 283-287.

3. M. C. Ansón CALvo, "Gaspar Zaydejos: destacado morisco aragonés”, Turiaso, XVI, 2001-2002, pp. 233-261, ahora en ID., Torrellas. Del esplendor morisco a la decadencia y la tendencia a su recuperación, Torrellas, Ayuntamiento de Torrellas, 2014.

4. Las cartas inéditas sobre la vicisitud de Gaspar Zaydejos han sido halladas en la British Library de Londres. Aquí manifiesto mi gratitud al profesor Rafael Benítez que, con generosidad, me ha proporcionado esa valiosa documentación. Ella nos aporta la visión de la Suprema de Madrid con palabras francas, fundamentales para entender el punto de vista institucional de la Monarquía hispánica sobre la cuestión.

5. J. Tedeschi, The Prosecution of Heresy. Collected Studies on the Inquisition in Early Modern Italy, New York, Binghamton, 1991, pp. 20-45.

6. Para la recopilación de algunos casos me he servido de la amable colaboración de Valentina Oldrati. 
con lagunas para finales del Quinientos - que es cuando se empiezan a guardar-y bastante completos a partir de 1600. Al ser disposiciones jurídicas en latín, ese tipo de documentación, sin embargo, aporta información muy sintética y carece de una descripción cualitativa para contextualizaciones más amplias.

El propósito de comentar estas ocurrencias responde a esa doble vertiente documental y jurisdiccional, que me ha empujado a estructurar el trabajo en tres apartados. En el primero describiré el perfil de estos moriscos imputados en Roma; en el segundo abordaré la vicisitud del mencionado Gaspar Zaydejos, el personaje que encarna el amanecer, el cenit y el ocaso de este fenómeno; en el tercero, pondré de manifiesto los conflictos jurisdiccionales surgidos entre la ciudad de Pedro y Madrid a raíz de las sentencias de absolución expedidas por el Santo Oficio romano en favor de estos perseguidos.

\section{¿QUIÉNES SON LOS MORISCOS QUE LLEGAN A ROMA?}

Catorce son los imputados moriscos detectados ante el vicario general de Roma de los que se guardan las abjuraciones. Pueden parecer pocos, pero no hay que olvidar que queda solo la documentación de tres años que, encima, tiene lagunas. Todos ellos son sponte comparentes y, excepto dos, son todos hombres $^{7}$. La única acusación contra estos individuos es la apostasía al islam, pero con matices: en tres casos se hace explícita referencia a la disimulación religiosa; en el de Michel Rubio, de Jarque, el imputado declara haber creído en Mahoma sin practicar ningún ritual (sin haber "fatto atto alcuno maometano" ${ }^{8}$ ); y el de Juan de Portugal, de Aranda de Moncayo, el declarante revela mantener una relación con dos mujeres a la vez, defendiendo la legitimidad en tenerla 9 .

Solo tres provienen de poblados fuera del reino de Aragón ${ }^{10}$. Aquí tengo que abrir un paréntesis, puesto que es normal preguntarse sobre el porqué de la huida de los moriscos aragoneses a Roma. Además, nos hallamos frente a una situación novedosa: los moriscos suelen huir de España hacia Berbería o Estambul y esta "era la prueba de su criptoislamismo"11: ahora bien, ¿cómo se po-

7. Las dos mujeres son Ana Arévalo de Trasmoz, de 29 años (TCD, ms. 1229, ff. 78r-81r. Roma, 12 de marzo de 1607), y María Franco de Torrellas, de 50 años (TCD, ms. 1229, ff. 438r-441v. Roma, 20 de noviembre de 1607).

8. TCD, ms. 1228, ff. 153r-154r. ACDF, Decreta 1603, c. 169v. Roma, 23 de julio de 1603.

9. TCD, ms. 1229, ff. 427r-429v. ACDF, Decreta 1607, c. 437v. Roma, 16 de noviembre de 1607.

10. Se trata de Pedro Martín Cania de Segovia, de 48 años (TCD, ms. 1228, ff. 37-40. Roma, 15 de marzo de 1603); Juan Adán de Baza (diócesis de Guadix) de 50 años (TCD, ms. 1238, ff. 201r203v. Roma, 17 de abril de 1608); Lorenzo Rodríguez, residente en Toledo, de 26 años (TCD, ms. 1238, ff. 225r-227v. Roma, 10 de mayo de 1608).

11. G. ColÁs LAtOrRe, "Cuestiones sobre los moriscos”, en Bibliografía y fuentes para el estudio de los moriscos aragoneses, Teruel, CEM, 2010, p. 14. 
sicionó el Santo Oficio ante estos moriscos que sí se fugan, pero lo hacen hacia la capital de la Cristiandad?

Según los datos más aceptados por la comunidad científica, el $20 \%$ de la población aragonesa está compuesta por moriscos ${ }^{12}$. De ellos, un $90 \%$ vivía en un marco rural dentro de señoríos, en condición de servidumbre ${ }^{13}$. Sin embargo, no caben dudas que los moriscos aragoneses están muy hispanizados e integrados entre los cristianos viejos ${ }^{14}$. Si tomamos por buena la definición de Covarrubias en el Tesoro, en la entrada tagarinos, como a menudo se les apellida ${ }^{15}$, leemos:

"los moriscos antiguos criados entre christianos viejos, en lugares de Castilla y Aragón, los quales saben igualmente nuestra lengua y la suya, de modo que apenas se pueden distinguir ni conocer, salvo por la orden que con ellos se tiene de que vivan en ciertos barrios" 16 .

A la altura de la segunda mitad del XVI hasta la expulsión, los aragoneses ya no visten con vestidos típicos ${ }^{17}$ y quizás la mayoría hablan el mismo idioma de los vecinos cristianos viejos, con los que se llevan bien, como ha querido demostrar Gregorio Colás Latorre sirviéndose de fuentes notariales y cívicas $^{18}$. No se trata -advierte el investigador-de una relación idílica, sino de un sustancial trato de "buena vecindad". Las representaciones conflictivas no son otra cosa que el fruto de una producción literaria ideológica cristiana-militante o ligada a fuentes inquisitoriales y, en general, eclesiásticas, que tienen el riesgo de vehicular la mirada del historiador. Una confirmación de todo ello se encuentra en la "inmaterialización" de los complots de los que los moriscos aragoneses están acusados, salvo los choques, de otra naturaleza, de fines del siglo XVI entre los pastores montañeses y los moriscos de las vegas.

La atención de la inquisición de Zaragoza hacia los moriscos es muy severa, y lo demuestra la constatación que, entre 1560 y el 1614, casi la mitad de

12. M.S. Carrasco Urgoiti, El problema morisco en Aragón al comienzo del reinado de Felipe II. Estudio y apéndices documentales, Teruel, CEM, 2010 (ed. orig. Valencia, 1969), p. 25.; J. REGLÀ, Estudios sobre los moriscos, Barcelona, Ariel, 1974 (ed. orig. Valencia, 1964), p. 79.

13. G. ColÁs LATORRE, "Cuestiones sobre los moriscos", p. 22.

14. G. COLÁs LATORRe, "Los moriscos aragoneses: una definición más allá de la religión y la política", Sharq al-Andalus, 12, 1995, pp. 147-161.

15. Es decir, los de la frontera (thagr) más al norte del islam: M. DE EPALZA, "El islam aragonés, un islam de frontera", Turiaso, VII, 1987, pp. 9-21.

16. S. De Covarrubias Orozco, Tesoro de la lengua castellana o española, Madrid, 1611, ad vocem.

17. I. LASMARíAS PONZ, "Cultura material de los moriscos aragoneses: vestido y apariencia”, en M.J. CASAus BAllester (coord.), Los moriscos en los señorios aragoneses. Actas de las Terceras Jornadas del Proyecto Archivo Ducal de Hijar-Archivo Abierto, Teruel, CEM, 2013, pp. 211-241.

18. G. COLÁs LATORRE, “Cristianos y moriscos en Aragón: una nueva lectura de sus relaciones y comportamientos en el marco de la sociedad rural", Mélanges de la Casa de Velázquez, 29, 2, 1993, pp. 153-169; ID., La bailía de Caspe en los siglos XVI y XVII, Zaragoza, Institución "Fernando el Católico" (CSIC), p. 26, nota 55. 
los juzgados por delitos de fe son moriscos ${ }^{19}$. Hay otro factor a tener en cuenta. Hasta la segunda mitad del XVI los moriscos se benefician de cierto amparo de los señores que los protege de los ataques inquisitoriales. Cuando en el pulso entre señores e Inquisición va imponiéndose paulatinamente la fuerza de la segunda, los moriscos se ven más sujetos a la merced de las pesquisas inquisitoriales. Por su parte los barones aragoneses persisten en el intento de protección de sus vasallos, incluso incitándoles a la desobediencia. Ello se hace patente en ocasión del bando para el desarme de los moriscos de 1559, que se vuelve a reiterar en varias ocasiones. Que los señores se queden sin vasallos armados es inconcebible. Incluso en 1575 hay señores que no quieren ejecutar las medidas de desarme: el duque de Villahermosa, el conde de Aranda, el señor de Ossera. No son nombres citados por erudición: de los señoríos de estos personajes provienen muchos de los moriscos que se autodenuncian en Roma ${ }^{20}$. Leyendo los relatos inquisitoriales, se podría pensar que los moriscos van armados para prepararse a respaldar una invasión argelina o turca, mientras que, como ha explicado María Soledad Carrasco, el armamento era propio de aquellos que viven en estados señoriales en conflicto con los vecinos:

“Entretanto el desarme de los nuevos convertidos, lejos de solucionar ningún problema, dio como resultado que volvieran a armarse clandestinamente. Hubo conatos de rebelión y algunas familias moriscas conciben imposibles sueños de autonomía y grandeza" ${ }^{21}$.

La Santa Sede no entra directamente en estas cuestiones porque no le competen. Debe parecerle evidente que la persecución morisca vaya más allá de meros motivos religiosos. Es lógico deducir las razones de la fuga de algunos aragoneses a Italia: la mejor fama que tenía el Santo Oficio romano a la hora de juzgar los apostatas de la fe católica y la conciencia que guardan los moriscos sobre la difícil reconsideración de una sentencia de los papas en materia de fe por los inquisidores españoles. Roma, en definitiva, tiene fama de ser una ciudad que liberaba: se configura como una meta para los esclavos que aspiran a

19. Porcentajes sobre el número total de causas de los moriscos procesados por siete tribunales del Santo Oficio, en R. CARrasco, Deportados en nombre de Dios. La expulsión de los moriscos: cuarto centenario de una ignominia, Barcelona, Destino, 2009, p. 200. En el reino de Valencia y en el de Aragón, excepto en el quinquenio 1571-75, la proporción de moriscos juzgados está siempre muy por encima del 50\% sobre el total de los perseguidos: véase el cuadro Procesados por la Inquisición según las relaciones de causas en R. BENítez SÁNCHEZ-Blanco, "La Inquisición ante los moriscos", en J. Pérez Villanueva y B. Escandell Bonet, Historia de la Inquisición en España y América, Madrid, BAC, 1999, vol. III, p. 733.

20. Aunque solo Giovanni Macchi (¿Juan de Almaedí?) confesó haber "tenuto un scoppietto in casa", y era de Calanda, localidad bajo la jurisdicción de la Orden de Calatrava: TCD, ms. 1228, ff. 148 r.

21. M.S. CARRAsco Urgoiti, op.cit., p. 75. Henry Lea (Los moriscos españoles, p. 330) cuenta que "en Torrellas se recibió gran cantidad de armas, traídas desde Vizcaya y los armeros informaron que la demandas por parte de los moriscos era incesante". 
su emancipación ${ }^{22}$ y para aquellos que se sienten víctimas de la dureza de la represión inquisitorial española o de una persecución política bajo tintes religiosos. Esta fama "se crea" y en ese sentido son decisivos los antecedentes que marcan jurisprudencia.

Los aragoneses son casi todos de la diócesis de Tarazona, una zona que cuenta con pueblos de mayoría morisca: con el fin de salir de España, ésta es una comarca de paso reconocida también en las rutas comerciales de los mercaderes moriscos castellanos ${ }^{23}$. En esta comarca, el pueblo morisco de Torrellas ${ }^{24}$, cuyos vecinos son los más representados en los registros romanos, es un punto de apoyo para los trajineros moriscos de Valladolid, Ávila o Segovia, que no sólo transportan mercancías, sino que participan de las redes moriscas para el intercambio de informaciones ${ }^{25}$. Es una precisión requerida para contextualizar la presencia tanto de los tres foráneos, como de los torrellanos. Según los inquisidores zaragozanos, esas informaciones sirven a los líderes bien para tratar con los turcos y los argelinos, bien para coordinarse con los demás moriscos de España -en particular los valencianos ${ }^{26}$.

Todavía no queda claro el itinerario emprendido por estos individuos para ir a Roma, pues solo en ocasiones queda rastro de ello. Lo más probable es que salen vía terrestre por Navarra y de allí se dirigen hacia Marsella, donde puede ser que se embarquen en un buque para Civitavecchia, el puerto papal, o continuen recorriendo a pie la costa tirrénica. No cabe duda que en estos viajes padecen robos y saqueos, como sugiere el caso de Pedro Martín de Segovia y de su mujer, que encima es cristiana vieja. Cautivados como "espías del enemigo" en Marsella, Pedro es puesto a remar en las galeras francesas y la mujer, vendida como esclava, acaba en Nápoles junto a otra señora que los acompaña. Los cónyuges pudieron finalmente reunirse. La mujer de Pedro obtiene el perdón en Nápoles y éste lo pidió a papa Clemente VIII, que lo absuelve en apenas pocos días de su sponte comparitio ${ }^{27}$.

Las sentencias van acompañadas por la lectura de la abjuración por parte del imputado. En ambas se pueden recoger detalles interesantes para reconstruir sus vidas y su religiosidad, aunque siempre es mejor usar ciertas cautelas. Se

22. S. DI NEPI, «Le Restitutiones ad libertatem di schiavi a Roma in età moderna: prime note su un fenomeno trascurato (1516-1645)», Dimensioni e problemi della ricerca storica, 2, 2013, pp. 25-52.

23. S. DE TAPIA, "Las redes comerciales de los moriscos de Castilla la Vieja: un vehículo para sus "complicidades»", Studia Historica. Historia Moderna, XI, 1993, pp. 231-243.

24. J. VAlLEJO ZAMORA, "Los moriscos de Torrellas entre 1495-1610: consideraciones demográficas", Turiaso, VII, pp. 281-324.

25. S. DE TAPIA, op.cit., pp. 235-237.

26. Sin embargo, según el Inquisidor general, Gaspar de Quiroga, aunque el ataque del Turco no es de descartar, éste no se produciría como acto de ayuda a los moriscos. H. PiZARRo LlORENTE, Un gran patrón en la corte de Felipe II. Don Gaspar de Quiroga, Madrid, Comilas, 2004, p. 307.

27. TCD, ms. 1228, ff. 37r-39v; ACDF, Decreta 1603, c. 54v (Roma, 6 de marzo de 1603. La comparitio tuvo lugar el 3 de marzo). 


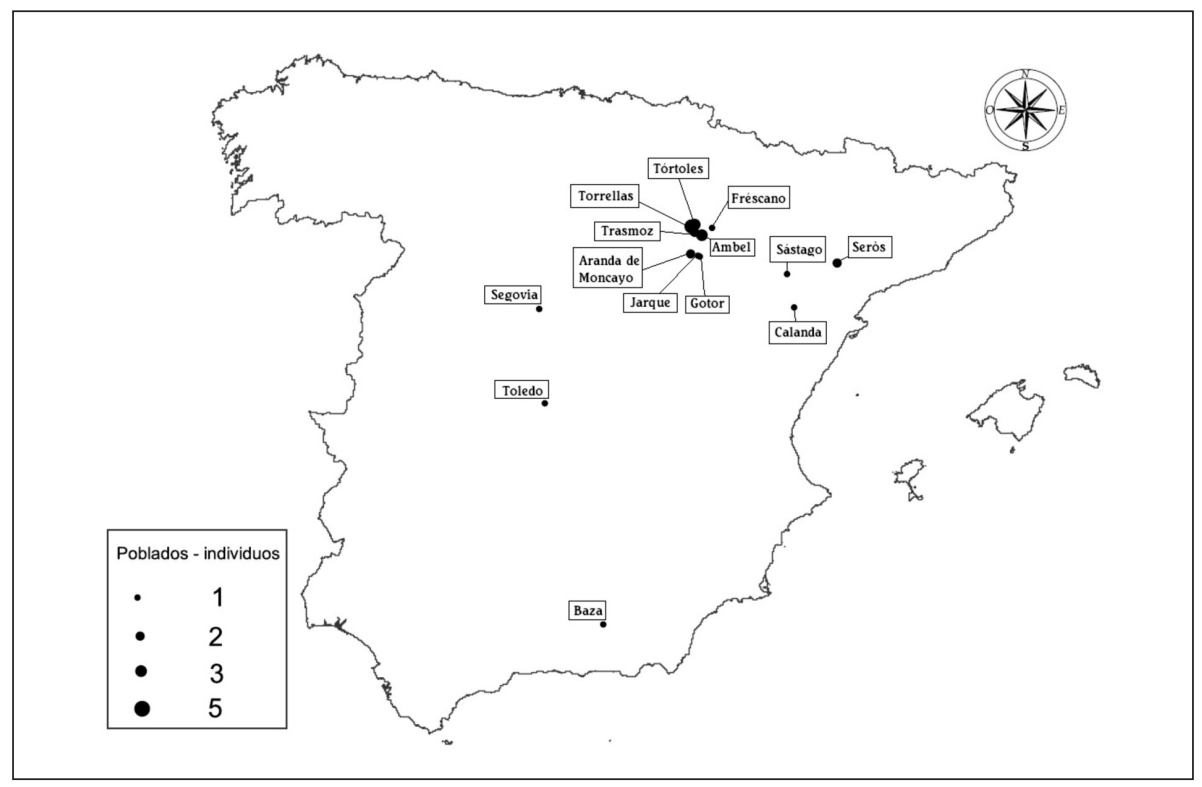

Origen de los moriscos sponte comparentes en Roma (1603-1609).

puede constatar, por ejemplo, una cierta homogeneidad en la edad de los sponte comparentes: sobre todo individuos entre los 40 y los 50 años. Aparece también la edad en que el imputado se convierte al islam, que suele ser entre los 10 y los 18 años, salvo algunos casos más tardíos. Todos declaran estar bautizados, conocer la religión católica y sus ritos. Se especifica el periodo de permanencia en el islam, así como quiénes han tenido un papel decisivo en la conversión:

- sujetos no identificados. Juan de Portugal, de Aranda ${ }^{28}$, y Juan de Granada, de Ambel $^{29}$, cuentan su entrega al islam con 18 años "a persuasione di una certa persona" sin especificar, que también les ha enseñado los rezos. El primero de los dos asegura haber vivido durante muchos años "a la moresca" y haber hecho proselitismo, enseñando "i precetti ad altri".

- un morisco viejo. El arriero Miguel Rubio, de Jarque, de 34 años se pasa al islam dos veces. La primera a los 15 años de edad, "persuaso da un altro", aunque entonces su permanencia es breve, apenas dos meses: "Vedendo tu che niuno de tuoi parenti facevano questi orationi, stimasti che fusse cosa falsa, et lasciando tale impietà, seguitasti a vivere christianamente nella fede cattolica". Ha caído otra vez en el "error" desde hace poco más de un año de

28. TCD, ms. 1229, ff. 427r-429v; ACDF, Decreta 1607, c. 437rv. Roma, 17 de noviembre de 1607.

29. TCD, ms. 1229, ff. 70r-72v. Roma, 10 de marzo de 1607; ACDF, Decreta 1607, cc. 265v-266r. 
su comparitio. Viajando a Toledo, se encuentra con un morisco viejo que lo convence alegando también que en las disputas entre cristianos y musulmanes, los cristianos acaban por ceder a los dogmas mahometanos ${ }^{30}$.

- la persuasión de un cónyuge, en particular de los maridos sobre sus mujeres. El ya citado Pedro Martín Cania, de Segovia, induce a su mujer "a la misma perfidia", tras el duro reproche del tío de Pedro contra el sobrino "per haver presa detta christiana vecchia per moglie"31. Ana Arévalo, de Trasmoz, de 29 años, que se autodenuncia en Roma y acusa al marido de haberse convertido al islam, abandonando del todo la "santa fede di Cristo" durante 10 años $^{32}$. Claro está que una muestra tan baja no prueba una tendencia, pero creo que, a pesar de lo que la historiografía ha defendido hasta ahora, debemos empezar a considerar que las mujeres tienen una facilidad de conversión al igual que los hombres, demostrando una apertura al cambio religioso ${ }^{33}$.

Asimismo se detalla la edad de reconversión del islam al cristianismo y los motivos de esa reconversión:

- la insistencia de la pareja: como el hombre persuade a su mujer para volverse musulmana, la mujer ruega a su marido el retorno al cristianismo. Retomando los avatares del susodicho Miguel Rubio, las etapas de su vida más reciente lo devuelven al catolicismo gracias a una "christiana vecchia, qual ti conferi che si voleva maritare con te convertito novo". Esta mujer, al parecer, resiste ante las exhortaciones de Miguel para abrazar la secta mahometana, y el morisco, a través de la "constanza di detta donna et aiutato dalla divina gratia, ti ravedesti dell'errore tuo, risolvendosi di lasciarlo affatto, et perciò ti sei recato a Roma a presentarti in questo Sant'officio et dimandarne perdono promettendo di voler viver christianamente tutto il rimanente di tua vita" ${ }^{34}$. El marido de Ana Arévalo, Juan de Lahuerta, de Trasmoz, que ha insistido con su mujer para su conversión al islam, es después "essortato dalla detta tua moglie a lasciar la detta setta".

- los sermones de un cura o la plática de un religioso: el mismo Juan de Lahuerta se da cuenta del camino equivocado, según relata, por haber escuchado más veces el reproche del cura contra el "errore" durante las prédicas; de forma parecida lo cuenta María Franco, de Torrellas, que ha vivido bajo las enseñanzas y ritos de Mahoma durante 39 años $^{35}$. Lope

30. TCD, ms. 1228, ff. 153r-154r. ACDF, Decreta 1603, c. 169v. Roma, 28 de julio de 1603.

31. TCD, ms. 1228 , ff. $37 \mathrm{r}-39 \mathrm{v}$.

32. TCD, ms. 1229, ff. 78r-81r.

33. De acuerdo con la opinión de G. FIUME, "Rinnegati: le imbricazioni delle relazioni mediterranee", en B. Franco, B. Pomara, M. Lomas, B. Ruiz-Bejarano (coords.), Identidades cuestionadas. Coexistencia y conflictos interreligiosos en el Mediterráneo (ss. XIV-XVIII), Valencia, PUV, 2016, p. 57.

34. TCD, ms. 1228, ff. 153r-154r.

35. TCD, ms. 1229, ff. 438r-441v. 
Alax, de Fréscano, 50 años,pasa tres años en las galeras, en consecuencia de una condena "per aver aderito alla setta di Mahoma". Regresado a su patria tras el servicio al remo, vuelve a vivir bajo la ley islámica por 23 años, hasta finalmente ceder ante los rezos de un religioso ${ }^{36}$.

- la conversación cotidiana con cristianos viejos ${ }^{37}$.

- otras situaciones puntuales: Juan Espinel, de Torrellas, declaró que su sponte comparitio, amén de producirse por haber "più volte ragionato con persone religiose" y con la ayuda de Dios, se ha visto animada por la lectura de las obras del dominico fray Luis de Granada ${ }^{38}$, porque entonces le "ven[n]e pensiero, che solo la religione christiana havesse la vera fede"39; singular la sentencia contra Juan Almaedí, de Calanda: los desastrosos negocios privados eran una señal divina de que si algo iba mal era por vivir en la falsa secta de Mahoma: "vedevi che per quanto sapevi travagliar et affaticar sempre andavi più in ruina, non sapendo dar la causa di questo ad altro, se non perché vivevi nella falsa setta di Mahometto".

No quiero dar más importancia a los motivos de reconversión al cristianismo, por dos razones. La primera es que éstos son también los habituales en las declaraciones ante la inquisición española y no extrañaría que el formulario de preguntas planteadas a los imputados por los inquisidores romanos fuera semejante al usado por sus colegas ibéricos. La segunda es que pueden parecer justificaciones pensadas sin mucha fantasía por los mismos comparentes para satisfacer los oídos de los ministros inquisitoriales: son frases estereotipadas que tal vez esconden la probable presencia de un mentor o un abogado que instruye a los moriscos y les sugiere lo más conveniente a declarar. En los interrogatorios hay intérpretes y llama la atención que aquí sea un cura de Tarazona, es decir de la diócesis de origen de la mayoría de aragoneses: ¿los había asesorado y acompañado hasta Roma?

Lo más asombroso de estos personajes es su estatus social. Notables en sus pueblos de origen, desempeñan cargos municipales y pertenecen a potentes grupos afectados por una tradición persecutoria inquisitorial hasta los días de la expulsión. Juan Espinel forma parte un "clan extenso y muy poderoso" de Torrellas, sus parientes apadrinan a muchos niños, es decir gozan de un prestigio reconocido por sus vecinos ${ }^{40}$. María Franco era hija de Gabriel, un jurado de Torrellas ${ }^{41}$. Juan de Vivas, el responsable del abastecimiento de agua del mis-

36. TCD, ms. 1229, ff. 434r-437v. Roma, 20 de octubre de 1607; ACDF, Decreta 1607, c. 438r. Abjuración de formali el 16 de noviembre.

37. Lo confesó Juan de Granada: TCD, ms. 1229, ff. 70r-72v.

38. Cuya obra completa es inmensa.

39. TCD, ms. 1228, ff. 422r-424v; ACDF, Decreta 1603, c. 264 r.

40. M. C. Ansón, Torrellas..., p. 305.

41. Ibidem, p. 201. 
mo pueblo ${ }^{42}$, tarea tan crucial en la economía rural morisca. De Gaspar Zaydejos se dirá más adelante.

Siete de ellos saben escribir y seis pueden leer (poseen libros moriegos) ${ }^{43}$. Juan de Portugal, de Aranda de Moncayo, admite haber transcrito de su mano y utilizado algunos "escritos pertenecientes a dicta secta" ${ }^{44}$. Juan de Lahuerta confiesa "haver ricevuto et tenuto presso di te per molti anni un libro continente in arabico l'orationi et cerimonie di detta setta" ${ }^{45}$; lo mismo manifiestan Juan Vivas, de Torrellas, Lope Alax, de Fréscano o Juan Adán de Baza. Pero se ha visto el caso opuesto del morisco Juan Espinel, que leía libros cristianos. En definitiva, los moriscos que llegan a Roma son personas cultas y bien informadas sobre donde hay que ir y cómo hay que defenderse. Algo que no nos extraña: los moriscos aragoneses son los más alfabetizados, tienen la producción más ingente de textos aljamiados en España ${ }^{46}$; de 900 condenados en Aragón, 409 entre ellos admiten poseer escritos de contenido religioso musulmán ${ }^{47}$. Hay escuelas secretas donde se imparten clases de ritualidad islámica, se enseña el Corán y se aprende el árabe; también el mercado negro de papeles, libros y cartas de los muertos en aljamiado o la presencia de bibliotecas con títulos árabes en casa de particulares son parte de una realidad extendida que involucra trasversalmente más grupos sociales ${ }^{48}$ :

“el número de libros, que supuestamente manejan los moriscos, resulta sorprendente para un mundo de iletrados. Las causas de fe hablan de moriscos que iban a una determinada casa a escuchar la lectura de un libro" ${ }^{49}$.

Declarándoles como apóstatas, el papa reconcilia a todos los moriscos de la excomunión con la abjuración de formali, acontecimiento que suele tener lugar en la iglesia dominica de San Nicola in Campo Marzio o en el propio palacio del Santo Oficio. La sentencia prevé una serie de leves penitencias espirituales, prácticamente iguales en todos $\operatorname{los} \operatorname{casos}^{50}$. A la sentencia se añade una cláusula

42. Ibidem, p 101.

43. Aunque en este caso caben pocas dudas que los sponte moriscos sepan leer, la posesión de libros "moriegos", como ilustra Mercedes García-Arenal, no es sinónimo de capacidad de lectura. Incluso analfabetas, de hecho, poseen estos libros como si fueran talismanes con función de protección. M. GARCía-ARENAL, "La Inquisición y los libros de los moriscos", en A. MATEOs PARAMIO (coord.), Memoria de los Moriscos: Escritos y relatos de una diáspora cultural, Madrid, Sociedad Estatal de Conmemoraciones Culturales, 2010, p. 71.

44. TCD, ms. 1229 , ff. $427 \mathrm{r}-429 \mathrm{v}$.

45. TCD, ms. 1229, ff. 82r-84v.

46. M. DE EPAlZA, “Introducción”, en L. F. Bernabé POns, El cántico del morisco hispanotunecino Taybili, Zaragoza, Institución "Fernando el Católico", 1998, p. 18.

47. J. FOURNEL-GUÉRIN, "Le livre et la civilisation écrite dans la communauté morisque aragonaise (1540-1620)", Mélanges de la Casa de Velázquez, 15, 1979, p. 243.

48. J. FOURNEL-GuÉRIN, "Le livre et la civilisation écrite", passim.

49. G. Colás Latorre, "Cuestiones sobre los moriscos", op. cit., p. 21.

50. La visita de las siete iglesias "privilegiadas" dentro y fuera de las murallas de Roma; ayunos (solo pan y agua) todos los viernes, durante tres años; recitación del rosario dos veces por se- 
que vincula su ejecución a la ausencia de antecedentes penales e indicios del sponte ante la Suprema ${ }^{51}$. Para llegar a consensuar esta cláusula, las dos inquisiciones pasan por un largo periodo de roces, que prosiguen incluso después. Madrid opta por pasar por alto la Santa Sede. Los sucesos de Gaspar Zaydejos abren y cierran esta historia de conflictividad, que tiene muchos paréntesis.

\section{GASPAR ZAYDEJOS Y EL “ESTALLIDO DEL CONFLICTO”}

Gaspar Zaydejos es uno de los líderes de las élites moriscas aragonesas ${ }^{52}$. Vive casi toda su vida en Torrellas, donde ocupa cargos importantes: es jurado, tablajero (es decir, un cobrador de los derechos reales) y justicia del pueblo. La tradición de su familia, asentada en Torrellas desde hace generaciones, es la de mercaderes consolidados no solo en el circuito aragonés, sino en toda la península ibérica ${ }^{53}$. Torrellas es un poblado muy importante de la diócesis de Tarazona, de la que dista apenas tres kilómetros, situado en un enclave de pueblos moriscos entre la castellana Soria y la frontera navarra. Ya se ha dicho que es un centro de encuentro entre varios moriscos, donde incluso se asientan los mercaderes moriscos castellanos que quieren salir por Francia, tal vez conspiradores en contra de la Monarquía. El término municipal pertenece a la señoría de los condes de Ribagorza, duques de Villahermosa, y está habitado por algo más de dos mil moriscos ${ }^{54}$. En la segunda mitad del siglo XVI, cuando empiezan a desarrollarse los hechos, el señor de Torrellas es el conde Juan Alfonso de Aragón y Gurrea, marido de Luisa de Cabrera y Pacheco, hija del marqués de Villena. Juan Alfonso es reo de uxoricidio: fugitivo, se refugia en Cremona, importante plaza militar del ducado de Milán, y allí es encontrado y detenido por las autoridades españolas ${ }^{55}$. La noticia deja de ser anecdótica si se pone en relación con la trayectoria biográfica de Gaspar Zaydejos. Éste, de hecho, es muy amigo del conde, incluso se le puede considerar como un criado "muy pri-

mana; arrodillarse cotidianamente por tres años y delante de la "sacra imagen", repitiendo cinco veces la oración dominical y la salutación angélica; confesión cuatro veces al año durante tres años, y otras cuatro con licencia de su confesor en Navidad, día de la Resurrección, Pentecostés y Todos los Santos.

51. La frase repetida en cada una de estas sentencias es la siguiente: "dopo la quale abiura saremo contenti assolverti dalle censure et pene ecclesiastiche nelle quali per le dette cose sei incorso, purché non sii provenuto d'inditii in alcun tribunal del Santo Offitio in Spagna".

52. Bárbara Ruiz-Bejarano esboza una prosopografía sobre algunas de estas figuras, en la documentación conocidas como caudillos: B. RUIZ-BEJARANO, Praxis islámica de los musulmanes aragoneses a partir del corpus aljamiado-morisco y su confrontación con otras fuentes contemporáneas, Universidad de Alicante, tesis doctoral inédita, 2015, pp. 438-465.

53. M. C. Ansón, “Gaspar Zaydejos...”, p. 238.

54. J. REGLÀ, op.cit., p. 82.

55. A. Canellas López, "Notas para la vida dramática de Don Juan de Aragón y Gurrea, conde de Ribagorza, ejecutado en 1573", Cuadernos de historia Jerónimo Zurita, 6-7, 1954, pp. 75-92; M. C. Ansón, "Gaspar Zaydejos...", pp. 241-244. 
vado" suyo. Un testigo lo acusa de participar al asesinato de la mujer del conde, una pista no corroborada por los jueces. La persecución inquisitorial contra Gaspar comienza justamente cuando el notable morisco pierde el amparo de su excelente protector: el vasallo Zaydejos es uno entre muchos que padece en carne propia la pérdida de competencias del señor local. A este particular hay que añadir el contexto de aquellos años: la recién apagada revuelta de las Alpujarras es una pesadillas para la Monarquía y los rumores de revancha y acuerdos entre infieles turcos, argelinos y demás moriscos de la Península (sobre todo valencianos y aragoneses), no dejan de estar muy presentes en las consideraciones generales sobre la amenaza morisca. El cronista Aznar Cardona reconoce en Gaspar Zaydejos el "diligente mensajero" que "traxo respuesta en espacio de dos años" del apoyo del Gran Turco ${ }^{56}$.

Imputado por la inquisición aragonesa a partir de 1573, de inmediato Gaspar Zaydejos escapa a Roma. En junio de 1574 depone ante el Santo Oficio romano $^{57}$. En 1577 decide volver a la ciudad tiberina. Tras un viaje duro y largo, pasa por Roncesvalles y Pau. Los informes secretos revelan que Gaspar se encuentra con un capitán de los luteranos, mientras que más adelante, en Marsella, se reúne con Martín Izquierdo -tal vez confundido con Jaime Izquierdo, otro de los principales cabecillas de los complots moriscos. Según los relatos del protagonista, en este duro viaje de 200 leguas a pie (poco más de 1.100 kilómetros) Zaydejos es atracado y constreñido a vender su capa para poder comer y arribar a Roma. Zaydejos se queda otros cuatro años en la ciudad del papa, donde acude al Santo Oficio por segunda vez, en esta ocasión para autodenunciarse. El carácter totalmente temporal de la estancia en Roma de los moriscos aragoneses está vinculado a los trámites burocráticos del proceso que podía durar incluso años. En este caso, Zaydejos parece esperar en Roma, ya que decide presentarse solo el 9 de mayo de 1580, "compareciendo libre y espontáneamente ante [...] Gregorio XIII" ${ }^{58}$. El 2 de marzo de 1581 el pontífice emite la sentencia de reconciliación como apóstata formal contra el aragonés, aplicando unas penitencias espirituales que en el decretum no están especificadas, aunque con mucha probabilidad no son distintas a las de los demás moriscos que, unos años después, van a Roma con semejantes intenciones ${ }^{59}$. La congregación romana debe poner al tanto a la Suprema para preparar el regreso de Zaydejos. Es el se-

56. P. Aznar CARdona, Expulsión justificada de los moriscos españoles, Huesca, 1612, f. 46v. Zaydejos es citado como mensajero también en el f. 40r.

57. ACDF, Decreta 1574, c. 955. Roma, 17 de junio de 1574. Tres años antes, pues, de lo que ha escrito María Carmen Ansón.

58. BL, Egerton, 1507, f. 110.

59. ACDF, Decreta 1581, c. 31rv: "Gasparis Zaedejios de Torreglia terraconensis diocesis in Regno Aragoniae. Audita eius spontanea comparitione in hoc Sancto Officio facta et errorum suorum confessione decretum et ordinatum fuit quod dictus Gaspar, facta abiuratione ut formalis apostata, absolvatur ab apostasia in i[sic] ei poenitentiis salutaribus, et reverendus commissarius generalis Sancti Officii illum expediat, ac demum commendetur Inquisitori maiori hispanium". 
cretario romano cardenal Giacomo Savelli ${ }^{60}$ quien se preocupa de escribir a su homólogo español, el inquisidor general, arzobispo de Toledo, Gaspar Quiroga ${ }^{61}$ :

“Gaspar Zaidejos [...] discendente di mori, havendo confessato in questo Santo Offitio, dove è comparso spontaneamente, l'error nel qual è incorso di haver apostatato [...] è stato ricevuto con misericordia e absoluto, e perciò ritornando se n'è spedito. Sua Santità ha ordinato che io l'accompagni con questa mia, con la quale prego a Vostra Signoria Illustrissima ad haverlo per riconciliato, non permettendo che per le cose passate sia più molestato" 62 .

¿Zaydejos espera solo la absolución papal, otorgada finalmente en marzo de 1581, para regresar plácidamente con ella a Aragón? ¿O va a Roma para negociar unos asuntos más amplios referidos a su entera comunidad? Mediante la documentación recogida en el Archivo Histórico Nacional, María Carmen Ansón ha afirmado que Zaydejos se marcha a la ciudad pontificia como representante de los moriscos aragoneses con el fin precipuo de pedir el respeto de un edicto de gracia concedido en 1555 por la Santa Sede y nunca aplicado, pese a que los moriscos pagaran una cuota anual de 35 mil sueldos ${ }^{63}$.

Cuando todavía Madrid no ha recibido el diktat pontificio, ya que seguramente el correo de Savelli estaría en viaje, el inquisidor Quiroga escribe al mismo secretario de la congregación romana para intimarle la remisión del preso Gaspar Zaydejos, "indiciado de aver sido y ser moro, como lo fueron sus pasados $^{\prime 64}$. En relación a esta acusación, el Santo Oficio romano lo acaba de reconciliar. Sin embargo, el perfil criminal de Zaydejos lleva también otra mancha, conectada al repetido tópico de tramar un levantamiento atribuido a los moriscos: es sospechoso de "aver tratado con los nuevos convertidos de aquel Reino de alguna conmoción". Zaydejos parece el hombre clave para destapar esta red y aclararía la posición de otros presos en las secretas zaragozanas. Ya que es el "hombre principal en su género en el reino de Aragón. Su deposición y declaración sería de mucha importancia para los cómplices de sus delictos”65.

60. Giacomo Savelli (1523-1587) fue inquisidor mayor desde 1577 y vicario de la diócesis romana desde 1570 (ambos oficios ocupados hasta su muerte). Sobre él, I. Fosi, Savelli, Giacomo, en A. ProsPERI (diretto da), Dizionario Storico dell'Inquisizione, Pisa, Edizioni della Normale, 2010, ad vocem.

61. Gaspar de Quiroga y Vela (1512-1594) fue obispo de Cuenca, arzobispo de Toledo, inquisidor general y miembro del consejo de Estado. En el séquito de Felipe II en su estancia en Andalucía, Quiroga ha seguido muy de cerca el desarrollo de la revuelta de las Alpujarras. En torno a su figura, H. PIZARRO LlORENTE, op.cit. Su postura cambiante hacia el conjunto morisco es así descrita por esta autora (p. 308): “Quiroga [...] respaldó los intentos de adoctrinamiento en la fe católica de los moriscos, su evolución fue semejante a la desarrollada por el conjunto de la Monarquía, decantándose, en los años ochenta, por la expulsión".

62. BL, Egerton, ms. 1507, f. 116. Roma, 4 de marzo de 1581.

63. M. C. ANSÓN, Torrellas..., p. 153. La renta anual es la cuota acordada en el marco de la concordia aprobada conjuntamente al edicto de gracia: M. GARCÍA-ARENAL, "La concordia de la Inquisición de Aragón del año 1555", en A. TEMIMI (ed.), Religion, identité et sources documentaires sur les morisques andalous, Tunis, 1984, tomo I, pp. 325-348; R. BENíTEZ SÁNCHEZ-BLANCO, op.cit., pp. 713-714.

64. AHN, Inq., libro 357, f. 88. Madrid, 14 de marzo de 1581.

65. Ibidem. 
Pasados unos meses, Zaydejos regresa a España y a finales de agosto se presenta ante el Santo Oficio de Zaragoza con su perdón otorgado por la Santa Sede $^{66}$. En su carta a Madrid, los inquisidores aragoneses notan cómo en la sentencia romana faltan demasiados cargos de incriminación: entre otros, el que concierne el hallazgo de unos escritos "de su mano" "en poder de Jaime Izquierdo", tocantes al "levantamiento de los moriscos deste Reino", que "tienen muchas palabras en favor y alabanza del turco y contra los christianos". Desde luego, son cuestiones que rebasan la esfera religiosa, pues se trata de traición al soberano y a sus instituciones, un delito de lesa majestad humana. Además, la Congregación romana no hace mención del delito de nefando, transgresión por la cual Zaydejos está asimismo culpado.

La reconciliación pontificia causa cierto desconcierto en la Suprema. La espontánea comparecencia en Zaragoza con el certificado papal (firmado por Adriano Flaminio de Montesanto, notario del Santo Oficio) no condiciona la actitud de la Suprema, que enseña su inflexibilidad sobre el asunto. De momento Gaspar Zaydejos permanece detenido en las cárceles cesaraugustanas ${ }^{67}$. Ni siquiera el memorial de sumisas disculpas del mismo imputado conmueve a los ministros de la inquisición española: "Sintiéndose en su consciencia muy gravemente culpado con muchos y varios delictos contra la divina Majestad cometidos, así de herejía y apostasía, como muchos otros", Zaydejos pide la "salvación de su alma", tal vez preocupado por jugarse la vida. El torrellano manifiesta su desasosiego sin darle más vueltas: "considerando la inmensa misericordia de Dios, que no quiere la muerte del pecador sino que se convierta y viva", decide confesarse en Roma, "pidiendo perdón" por todo ${ }^{68}$.

El inquisidor general Quiroga entiende que, por otra parte, el arresto de Zaydejos representase una falta de respeto y un desafío a la Santa Sede. Sobre todo porque afecta la relación entre Su Santidad y el rey, a la sazón en un "estadio [...] que es de poca satisfacción":

“En Roma tienen por cierto que en España se tiene poca obediencia y reverencia a las cosas de aquella corte y a los ministros que acá tiene Su Santidad (a lo menos en los tribunales reales) y si ahora viesen que en el Santo Oficio se tratan los negocios de Roma como en los tribunales seglares [...] harían juicios y discursos contra la Inquisición de lo qual podría resultar en mucho daño del Santo Oficio" ${ }^{\prime 69}$.

Otros dos puntos atormentan a Quiroga, uno como consecuencia del otro. El alto prelado valora con un balance positivo el trabajo desempeñado hasta entonces por la Inquisición. Indultar a Zaydejos implicaría el comienzo de una oleada de moriscos que pronto se marcharían a Roma con los mismos

66. BL, Egerton, 1507, f. 188. Zaragoza, 31 de agosto de 1581. Los inquisidores de Zaragoza al Consejo inquisitorial de Madrid.

67. Ibidem, al margen.

68. BL, Egerton, ms. 1507, f. 110.

69. BL, Egerton, ms. 1507, f. 112. Toledo, 11 de septiembre de 1581. El inquisidor Quiroga al Consejo. 
fines. Roma perdona, Madrid toma nota. No, la Monarquía no puede permitirse frustrar el largo proceso de desarraigo del islam de España:

"Por otra parte parece cargo de conciencia que un hombre tan facineroso como éste quede sin castigo [...] y lo que peor sería es que tomarían ocasión y ejemplo deste caso para irse muchas personas por el camino que ha ido y venido el Zaidejos, en mucha desautoridad del Santo Oficio y daño de la república cristiana. Pues por esta vía quedarían sin castigo los herejes y apóstatas y se tornaría a plantar en España la sucia y maldita secta de Mahoma"70.

El procedimiento propuesto por Quiroga es el de volver a examinar todos los cargos procesales de Zaydejos y cotejarlos con el testimonio y sentencia de Roma. El objetivo tiene que ser la averiguación de si el morisco había confesado todos sus pecados delante del pontífice. El asunto era demasiado importante para que el rey no fuera puesto al corriente de todo y no opinara al respecto. Su Majestad ya ha enviado un agente ante la Santa Sede para tratar la cuestión. Evidentemente el asunto no está cerrado, Felipe II tiene que escribir a Roma y acompañar la carta con un emisario. Éste tenía que conseguir "con mucha instancia que, a los que fuesen a Roma en esta manera, los tornasen a remitir a España". Al papa se le puede tranquilizar asegurándole que en los reinos españoles la justicia se guarda "muy cumplidamente y quando los inquisidores faltasen en algo el Consejo lo remediara". Viceversa, el Santo Oficio español -prosigue Quiroga- sale desautorizado dando "ocasión para que cada uno viva como le paresciere". Ante los ojos de Quiroga, la institución inquisitorial española de esta manera sufriría una involución desde su fundación y el negocio "Zaydejos" asume por lo tanto una importancia crucial: "En tiempo de los Reyes Católicos, de gloriosa memoria, no se consentía que ninguno en las cosas de fe se valiese de Roma. Esto es lo que agora me parece. Holgara harto de hallarme presente para oyr a Vuestra Magestad porque el negocio es de calidad que conviene mirarle con ambos ojos en este tiempo"71.

No es cierto lo que afirma Quiroga. Como ha destacado Henry Charles Lea, el nudo de las apelaciones a Roma tiene un largo recorrido histórico a partir de la fundación inquisitorial ${ }^{72}$. En torno a las cuestiones de fe, Roma puede siempre recurrir a la consabida superioridad pontificia y, si se da el caso, mostrar su fuerza ante Madrid, avocando la causa para tener la última palabra en las controversias jurisdiccionales. Y, por ello, muchos empiezan a apelar a la máxima autoridad religiosa de la cristiandad, si bien estos recursos implican unos gastos exorbitantes: la búsqueda de expertos abogados conocedores del derecho canónico, una suma de dinero para "comprar" la reconciliación romana y, si no se puede operar en la distancia, el coste del viaje hasta la ciudad papal.

70. Ibidem.

71. Ibidem.

72. H.C. LEA, Historia de la Inquisición española, Madrid, Fundación Universitaria Española, 1993, vol. I, pp. 721-783. 
Con palabras tajantes de Lea, "la clemencia negada en España podía ser comprada en el mercado abierto de Roma"73.

Las apelaciones a Roma por individuos españoles, pues, fastidian a los inquisidores de la Suprema que ven así afectada su arraigada y celosa independencia institucional. Célebre es una consulta de los inquisidores a Felipe II en 1583, en la cual se perciben tonos agrios. En ella a los ministros eclesiásticos no sienta bien la interferencia de Roma en los procesos inquisitoriales españoles. El rey tiene que persuadir al papa Gregorio XII “de que no admitiese las apelaciones, las cuales deberían ser remitidas al Inquisidor General" ${ }^{74}$ :

"Muchas vezes se a representado a Vuestra Magestad la mucha mano que en Roma toman en las cossas tocantes al Sancto Officio, recibiendo de buena gana y mirando con buenos ojos a los que allá acuden, aunque ayan quebrantado acá las cárceles de la Inquisición y se vayan huyendo, remitiéndoles las penas que acá se les an impuesto, galeras o destierros, alçándoles las cárceles y quitándoles los hábitos en que fueron penitenciados, y haziendo en effecto con mucha facilidad lo que se pretenden y piden, y muchas vezes por solas sus confesiones, sin entender los méritos de sus causas, ni qualidad de sus culpas, en gran desauthoridad de la Inquisición de estos reinos. Bien conocemos y confesamos todos que Su Santidad y su Sancta Sede apostólica es el supremo juez y tribunal en estas y otras qualesquier causas ecclesiásticas, pero no siempre conviene hazerse todo lo que se podría, y considerando esto los Romanos Pontífices, sus predecesores, an concedido diversos breves y bullas advocando a sí las causas de heregía y cometiéndolas a los Inquisidores Generales que por tiempo an sido y son en España, y suspendiendo otros qualesquier que ayan dado en contrario, y no se han de entender que era por ser menor su jurisdicción que agora, sino por evitar muchos inconvenientes que de lo contrario resultan, porque por esta vía se quita el nervio a la Inquisición de estos reinos, confúndese su buen procedimiento y dirección de las causas que en ella se tratan, dase mucha ocasión e incentivo para que se cometan más y mayores delictos con sperança de perdón. El Inquisidor General, qualquiera que sea, no tiene fuerça para resistir a esto, ni para más que obedecer y cumplir lo que se manda, pero tiénela Vuestra Magestad para representar con su poderosa mano, por medio de su embaxador, los inconvenientes que de aquí resultan contra nuestra religión y el bien público de sus reinos. Y assí suplican a Vuestra Magestad el Inquisidor General y Consejo lo aga por lo mucho que importa, que si ya no se remediare del todo, a lo menos servirá para reprimir mucho" ${ }^{\prime 75}$.

73. Ibidem, p. 722.

74. C. Fernández Giménez, "Problemas del Consejo de la Inquisición en el reinado de Felipe II", Revista de la Inquisición, 10, 2001, p. 200.

75. Cit. en C. FERnÁndez GiménEZ, op.cit., pp. 206-207. El debate sobre las apelaciones es uno de los principales en la correspondencia entre Roma y Madrid: H. PIZARRO LlORENTE, op.cit., pp. 321, 323-329; R. DE HinojosA, Los despachos de la diplomacia pontificia en España. Memoria de una misión oficial en el archivo secreto de la Santa Sede, Madrid, 1894, tomo 1, p. 254, quien ha hablado de "apelaciones interpuestas por los aragoneses sobre todo". 
Mientras tanto, la situación de Zaydejos se va complicando y, desde Toledo, Quiroga acaba por sugerir al consejo de la Inquisición que la solución adecuada es "mandar soltar" al cabecilla morisco "porque no se quexe en Roma diciendo que de lo que le sirvieron los recaudos que traxo de allá fue de mandarle prender luego acá; y cierto, lo tomarán muy mal, y tanto peor cuanto más y mayores personas entendieron en su despacho" ${ }^{\prime 76}$. Finalmente, en diciembre del mismo año el aragonés es liberado tras el pago de una fianza y puesto bajo control en Torrellas ${ }^{77}$.

El transcurso inquisitorial de Zaydejos quedaría aparcado unos años. De momento, el torrellano vive otra vez en su ciudad y consigue restablecer su liderazgo. Vuelve a ocupar el cargo de jurado e, incluso, el más prestigioso de justicia ${ }^{78}$. Un liderazgo que va más allá de la comunidad torrellana ya que en 1589 el morisco obtiene una licencia para desplazarse a Madrid y a San Lorenzo de El Escorial junto a otros destacados moriscos aragoneses, "donde puedan estar todo el tiempo que el señor conde de Sástago (a quien van dirigidos) les concediere $^{\prime \prime 7}$. Es decir, Zaydejos sigue negociando algo - ¿el tema del desarme? ¿Un edicto de gracia?- con las altas esferas de poder. Además, en la primera década del siglo XVII, en sus actividades económicas el morisco torrellano no ha ralentizado su dinamismo ${ }^{80}$, pese a las persecuciones judiciales padecidas, que lo constriñen al pago de una fianza nada irrelevante. Testimonios de vecinos lo señalan como participante en ceremonias funerarias "a la morisca", dueño de libros moriegos e intérprete de los mismos en su propia casa en beneficio de amigos y conocidos, y lo catapultan de nuevo frente a la inquisición de Zaragoza. En los mismos años caen víctimas de sus pesquisas también la hermana Jerónima ${ }^{81}$ y el hermano Baltasar ${ }^{82}$. En septiembre de 1607, pocos meses antes de volver a ser detenido por la Inquisición, Gaspar regresa a Madrid con una licencia que le permite hablar con el soberano y los mayores representantes de la Suprema, "porque tiene algunas cosas de importancia que dar cuenta" $^{83}$. El "caso Zaydejos" se vuelve a plantear entre inquisición española

76. BL, Egerton, ms. 1507, f. 114, nota al margen. Madrid, 16 de septiembre de 1581. El Consejo a Quiroga y respuesta al margen de Quiroga al Consejo. Escribe Pizarro Llorente: "Sospechaba que algunos cardenales de la congregación del Santo Oficio habían persuadido al Papa de que el Inquisidor General y el Consejo guardaban poco respeto y obediencia al pontífice, puesto que no le informaban de los negocios que trataban ni se cumplían las órdenes que se remitían desde la Santa Sede". H. PiZArro Llorente, op.cit., p. 328.

77. M. C. Ansón, “Gaspar Zaydejos...", p. 251.

78. Ibidem, p. 252.

79. AHN, Inq., libro 357, f. 271. Madrid, 12 de mayo y 7 de junio de 1589. Licencias de los inquisidores de Zaragoza para Miguel Chico de Villafeliche, Fevrer Ginete de Bardallur, Juan de Almatar de Mores y Gaspar Zaydejos.

80. M. C. Ansón, “Gaspar Zaydejos...., pp. 255-256.

81. Ibidem.

82. M. C. ANSÓN, Torrellas..., p. 211.

83. M. C. Ansón, “Gaspar Zaydejos...”, p. 257. 
y Santo Oficio romano cuando la primera pide a la segunda la copia de la sentencia de absolución y abjuración del torrellano de marzo de $1581^{84}$. En esta ocasión el papa manda el duplicado de lo solicitado por Madrid mediante el agente inquisitorial español en Roma ${ }^{85}$.

En las secretas de Zaragoza, Gaspar Zaydejos recuerda haber vivido siempre como cristiano y haber sido reconciliado en Roma. En su contra, hay un testimonio de otros internados que lo ven realizar ceremonias de moros también detrás de los barrotes. Bajo tormento, Gaspar rehúsa todas las acusaciones. En noviembre de 1609, a los dos meses de la publicación del decreto de expulsión de los moriscos valencianos y unos meses antes del bando contra los aragoneses, Gaspar Zaydejos es condenado. Debe cumplir su pena: además del desfile público con sambenito junto a otros muchos moriscos, el tribunal falla a favor de un castigo de ocho años de galeras, cien latigazos y cien ducados en razón de los gastos del Santo Oficio. Con sus setenta años su condena no es ejecutada: Gaspar Zaydejos de Torrellas muere en la cárcel penitencial de Zaragoza un mes después del auto de $\mathrm{fe}^{86}$. El duque de Villahermosa contribuye a su entierro con veinte sueldos, última evidencia que corrobora la vinculación todavía existente entre los señores de Torrellas y el líder de la comunidad morisca. Esta sentencia y otras muchas pasan desapercibidas en Roma y no produjeron más tensiones diplomáticas de las que, en realidad, va a haber a raíz de la expulsión no comunicada a Paulo V.

\section{LAS TENSIONES HISPANO-ROMANAS}

Visionarias son las vivas intranquilidades inquisitoriales de 1581, expresadas en la carta ampliamente mencionada que Quiroga dirige a los demás componentes del consejo de la Suprema: el antecedente de Zaydejos se convierte en la esperanza de otros muchos aragoneses, animados por el cierre de la primera fase del proceso de Zaydejos, cuando éste es liberado por la inquisición aragonesa que no ha querido oponerse frontalmente a la sentencia de absolución de Roma. Tal vez por su propia boca, Zaydejos abre el paso a los viajes de unos cuantos moriscos de su comarca: enterados de los rumores locales sobre la posibilidad de una imputación ante los inquisidores aragoneses, éstos abandonan la península ibérica rumbo a Italia, en búsqueda de la benevolencia papal. Hasta principios de 1600, como he comentado en las páginas anteriores, disponemos de decreta incompletos y muy pobres de informaciones. Es

84. AHN, Inq., libro 332, f. 233v. Madrid, 23 de marzo de 1609. El consejo de la Inquisición al Santo Oficio romano.

85. ACDF, Decreta 1609, c. 186. Roma, 14 de mayo de 1609; AHN, Inq., libro 332, f. 247r. El consejo de la Inquisición a la inquisición de Zaragoza: “el agente de la Inquisición en Roma ha remitido el testimonio de la reconciliación y absolución de Zaydejos".

86. M. C. Ansón, “Gaspar Zaydejos...”, p. 259. 
legítimo deducir que, por ejemplo, Juan de Torrellas, sponte comparente demandante de la reconciliación para "ser recibido en el seno de la Santa Madre Iglesia" en Roma, sea morisco ${ }^{87}$ : aunque la fuente es escasa de detalles y no describe el cargo de Juan, se puede deducir porque sabemos que Torrellas es un pueblo habitado solo por cristianos nuevos. El motivo de la escasa presencia de moriscos en los registros vaticanos del último cuarto del XVI no se debe solo a la naturaleza de los decreta de esa época. Otro factor a tener en cuenta es que los moriscos aragoneses confían en que se les conceda un nuevo edicto de gracia. La negociación de los edictos tiene cierta tradición entre los moriscos de Aragón y de Valencia, a partir de los años treinta del siglo XVI. La inmunidad derivada de los edictos implica una inhibición inquisitorial; en cierto sentido consiente que los moriscos sigan viviendo a su manera ${ }^{88}$, aunque de modo fluctuante debido al carácter temporal de la medida ${ }^{89}$. En 1589 una comisión de tres moriscos aragoneses formaliza la solicitud, pidiendo el perdón general de su comunidad con el simple recurso al foro interno de la conciencia. La petición prevé una inacción inquisitorial durante un periodo limitado de tiempo en el que los moriscos, por su parte, tendrían que ser adoctrinados. Las penas infligidas a los hombres pertinaces jamás contemplarían la relajación, mientras que a las mujeres culpables se les impondría el sambenito y, si procediera, la cárcel en su lugar de origen. Una junta especial se forma para tratar la cuestión. La negociación dura años. En 1593 la Junta aprueba el edicto con unos cambios respecto a la propuesta remitida por los representantes moriscos. En la medida de indulgencia, vigente para cuatro meses, no están contemplados aquellos que ya están en la cárcel, en las galeras, los desterrados, los condenados a penas extraordinarias o los que todavía tengan pendiente la resolución de su causa. La contrapartida es la definitiva entrega de las armas y de los libros y papeles concernientes a la secta mahometana ${ }^{90}$.

A partir de estas fechas los moriscos no son los únicos en escaparse a Roma para evadir de la red inquisitorial española: lo hacen también presuntos sodomitas y zoófilos de los pueblos de las mismas diócesis de Tarazona y de Zaragoza, pero también de otras partes de España ${ }^{91}$. Es evidente que corre la voz: en contra de lo que los cronistas apologéticos afirman, los moriscos interactúan e intercambian opiniones y consejos con los cristianos viejos. Estos movimientos de personas involucran a toda la escala social, desde individuos acaudala-

87. ACDF, Decreta 1581, s.f. Roma, 31 de mayo y 7 de junio de 1581. Lo mismo se podría decir sobre Juan Ruiz de la diócesis de Tarazona: ACDF, Decreta 1592-93, s.f., sin fecha.

88. M. GARCíA-Arenal, “La concordia de la Inquisición de Aragón...”, p. 330.

89. J. P. DEDIEU, “L'Inquisition face aux morisques: aspects juridiques”, en L. CARDAILLAC (sous la direction de), Les morisques et l'inquisition, Paris, Publisud, 1990, pp. 117-118.

90. Las fases de la negociación del edicto están reconstruidas en H. PIZARRO LLORENTE, op. cit., pp. 536-541.

91. Los casos son demasiados numerosos como para no acotarlos en una nota a pie de página. Consúltese una muestra de ello en BC, ms. 3825, cc. 21r, 84v, 162v-163r, 144rv (año 1600) o las abjuraciones esparcidas en los volúmenes ya citados del Trinity College of Dublin. 
dos hasta pastores pobres, aunque en su mayoría son los primeros los que se fugan por las razones relativas a los costes, arriba explicitadas. Sin dudas, el mayor vaivén de moriscos se ocasiona a partir de 1602, es decir desde que el Santo Oficio romano opta por no ratificar otro edicto de gracia propuesto por el inquisidor general, Juan de Zuñiga, en favor de los moriscos de los reinos de Aragón y Valencia ${ }^{92}$. Es de suponer que a este indulto se han agarrado las esperanzas de muchos moriscos que ven así demolidas sus expectativas. Hay que recordar que la primera década del XVII es testimonio de la mayor oleada represiva contra los moriscos aragoneses. Dado este contexto, es comprensible que haya casos de familias que no quieren volver y solicitan una licencia para quedarse en la ciudad de Pedro ${ }^{93}$.

Por su parte, la Santa Sede aporta su granito de arena en la lucha para el desarraigo del islam, enviando indicios y señalando otros nombres de moriscos acusados de manera espontánea (es decir, sin padecer tormentos) por los sponte compaisanos: "examinetur in causa scientiae circa singulos quos nominat; deinde mittatur copia Inquisitori Hispaniarum" ${ }^{94}$. Hay quiénes, como el alafán de aguas Juan Vivas y María Franco, de Torrellas, llegan a acusar a cinco personas de ambos sexos, o Juan de Portugal, vecino de Aranda, quién delata a diez ${ }^{95}$. Una pequeña prueba de que la solidaridad nacional morisca es un concepto muy opinable en el caso aragonés (muy diferente al valenciano), como ya ha puesto de manifiesto Gregorio Colás Latorre ${ }^{96}$. Puede que estas acusaciones escondan la sombra de lucha entre bandos moriscos distintos. Lo hace pensar la acusación de Juan Lahuerta, de Trasmoz, marido de Ana Arévalo, contra Jerónimo Espinel ${ }^{97}$, miembro de un importante clan de Torrellas, ya acusado en 1597 por poseer los libros de Sergius y Calvino ${ }^{98}$; o las delaciones de Juan Vivas y María Franco contra los Díaz, Gabriel y Rodrigo, familia de las principales y

92. ACDF, Decreta 1602, cc. 293 y 348. Roma, 20 de junio de 1602 y 18 de julio de 1602. En particular este último: "De concedendo indulto recipiendi Mauros regni Aragoniae et Valentiae, duraturo per quadriennium. Lecto memoriali exhibito nomine regis Catholici, auditis votis Illustrissimorum dominorum etc. Sanctissimus noluit illud concedere, nam pro illorum instructione fuit provisum deputando parochos, eorumque prelatii compaverunt, ac spatio quadriennii videretur eis concedi libertas conscientiae".

93. ACDF, Decreta 1604-1605 (copia), cc. 690 (15 de junio de 1605), 697 (17 de junio), 754-755 (20 de julio). Alejos Albariel (o Albañol), Juan de Urrea, María Bárbaro y dos hijos "velint manere in Urbe an vero reverti in Hispaniam". El papa delibera que "ne recedant ab Urbe", pero siempre con la cláusula "dummodo non sint praeventi inditiis in Sancto Officio Hispaniarum". Sobre los Albariel, familia de ricos mercaderes víctimas de persecuciones inquisitoriales, véase FOURNELGUÉRIN, Les morisques aragonais et l'inquisition de Saragosse (1540-1620), tesis doctoral inédita, Université Paul Valéry de Montpellier, 1980, pp. 106-108.

94. ACDF, Decreta 1603, c. 264r. Roma, 2 de diciembre de 1603. Sentencia contra Juan Espinel de Torrellas.

95. ACDF, Decreta 1606, cc. 473rv. Roma, 16 de noviembre de 1607.

96. G. ColÁs Latorre, “Cuestiones sobre los moriscos...”, p. 14.

97. ACDF, Decreta 1607, cc. 256v-266r. Roma, 2 de marzo de 1607. Juan Lahuerta indica al Santo Oficio romano también a Francisco Amet de Berbería, moro no bautizado.

98. J. Fournel-Guérin, "Le livre et la civilisation écrite", p. 253; M. C. Ansón, Torrellas..., p. 208. 
acaudaladas de Torrellas, contra el mercader Gabriel Gutiérrez, o contra Jerónimo Alcalde ${ }^{99}$. Sin embargo, estos personajes citados en Roma habían sido condenados a galeras en su patria unos años atrás. Se trata, entonces, de salir del paso descargándose las consciencias sobre los ya culpados y aparecer como colaboradores realmente arrepentidos frente a la Santa Sede.

De todas formas, la reacción de la Suprema en contra de aquellos que vuelven con el certificado papal de absolución no es unilateral. Los miembros del Consejo madrileño recomiendan a los inquisidores locales tratar con guante blanco a algunos de los moriscos regresados de Roma; en los casos de moriscos que no han confesado el delito de posesión de armas ante el pontífice, acusación afín a un posible levantamiento en España, casi siempre los inquisidores aragoneses acaban por pasar por alto las absoluciones de Roma. Desde luego, ¿por qué el papa debería entrar en el castigo del armamento de los moriscos? No le compete. En Aragón, en cambio, como se ha descrito, la Inquisición está encargada de reprimir la posesión de armas, ante una extendida inacción señorial ${ }^{100}$. Aquí presentaré cuatro casos distintos, que ejemplifican más de cerca la problemática.

El primero es el de Gabriel Çafar ${ }^{101}$. Perteneciente a una familia principal de Huesca, sus padres y un hermano han sido relajados al brazo secular por participar en la supuesta conspiración. Otro hermano, el calcetero Jusepe, es capturado al irse a Argel: se defiende diciendo que quería ir a Italia. Gabriel vuelve a acusar a su hermano Jusepe para que se le incoe de nuevo, confirmando su voluntad de escaparse a Argel. Quizá Gabriel atribuye la culpa a su hermano para aparecer frente a la autoridad inquisitorial como una persona transparente, pues el espectro de haber viajado a terra infidelium amenaza también su impunidad. Sin embargo, Gabriel es imputado por tomar parte en la organización del levantamiento nunca ocurrido. Notario, Gabriel Çafar cuenta haber viajado al menos dos veces hasta Roma. No niega haber visitado también Constantinopla y Argel, pero "no le satisfizo la vida de allí y regresó" a Aragón ${ }^{102}$. Condenado a galeras, Gabriel huye de las mismas para pasarse a Roma "en búsqueda de una conmutación de su pena a galeras por una más suave" ${ }^{103}$. En 1585 se le confirma la misma pena por la cual ha sido condenado unos años antes. Pienso que no se le aplica una pena más dura por fugitivo, lo normal en otros casos, justo por la interposición de la sentencia romana de absolución. La cual, a su vez, como

99. Todos estos indiciados aparecen en M. C. Ansón, Torrellas..., pp. 119, 211, 259, 272, 303.

100. En 1575 se cuentan un total de 5.406 armas confiscadas: B. Vincent, A. Domínguez OrTiz, Historia de los moriscos. Vida y tragedia de una minoría, Madrid, Alianza, 1985, p. 66.

101. A. Conte Cazcarro, "La Inquisición y los moriscos de la ciudad de Huesca", en Homenaje a don Antonio Durán Gudiol, Huesca, Instituto de Estudios Altoaragoneses, 1995, pp. 223-227; sobre los Çafar, véase también ID., "La decadencia de la aristocracia morisca: el caso de los Çafar de Huesca", Sharq Al-Andalus. Estudios Mudéjares y Moriscos, 14-15, 1997-1998, pp. 177-201.

102. A. Conte Cazcarro, "La Inquisición y los moriscos...", p. 224.

103. Ibidem. 
he tratado de explicar en las páginas anteriores, contiene la cláusula de anulación del quatenus non sit preventus inditiis in Sancti Officii hispaniarum.

La vicisitud de Gerónimo de Aimerit, de Seròs, diócesis de Lérida, es parecida a la de Gabriel Çafar. En marzo de 1606 Gerónimo comparece en Roma junto a su hermano Juan. Mientras que Juan es reconciliado de formali cum clausula, Gerónimo es llevado ante el papa para que aclarara su historial ${ }^{104}$. Un par de meses después el agente de la inquisición española en Roma solicita la devolución de Gerónimo por huir de las cárceles de la Suprema y ahora hallarse en las romanas ${ }^{105}$. Su caso genera un repaso de los registros decretales sobre los antecedentes ocurridos ${ }^{106}$. De común acuerdo, los inquisidores romanos determinan que Aimerit sea entregado al marqués de Villena, a la sazón embajador católico ante la Santa Sede, a efecto del traslado a la Inquisición de la que está huyendo. El Consejo madrileño intenta alentar a los ministros romanos, escribiéndole que a los inquisidores aragoneses, que ahora tienen el preso en su custodia, se les ha recomendado tratarlo "blanda y benignamente", "en consideración de haberse ido a los pies de su Santidad y lo mismo se hará con todos los demás que de esta corte se remitieren" ${ }^{\prime 107}$. En nombre del mismo respeto a Roma, la causa debe despacharse "con brevedad" y poner al tanto al papa sobre la pena aplicada, pues el mismo pontífice "se ha quexado que no lo hazéys" $^{\prime \prime 108}$. Lo sucedido con Gerónimo Aimerit constituye un antecedente que crea jurisprudencia. El tema de los fugitivos de la península ibérica, por lo visto un problema recurrente, es contemplado a partir de este caso ${ }^{109}$. De Madrid se aplaude el gesto de entrega del preso al embajador: un "estilo que siempre se ha guardado en estos casos" para no "agraviaros [...] pues demás de vuestro trabajo se escusa la costa que se haría a la Inquisición" ${ }^{\prime 110}$.

104. ACDF, Decreta 1606, c. 96r. Roma, 31 de marzo de 1606. La absolución de Juan con la expedición del certificado se halla en c. 220r (29 de diciembre de 1606).

105. ACDF, Decreta 1606, c. 110r. Roma, 15 de marzo de 1606.

106. La Congregación sacó a la luz tres antecedentes similares: el de Miguel Blanco de Ciudad Real, sponte a Roma el 13 de julio del 1583; el de Simón de Venodria de la diócesis de Lérida, sponte el 2 de septiembre de 1585; el de Gonzalo Sánchez de Castro San Martín, sponte el 23 de diciembre de 1586. ACDF, Decreta 1606, c. 121r. Roma, 6 de julio de 1606 . Tal vez hubo un caso más famoso, el de Jaime Sánchez alias Juan Berri, acusado de luteranismo por el tribunal de Zaragoza en los años ochenta y huido a Roma por estas fechas. Acerca de éste: H. PIZARRo LLORENTE, op.cit., pp. 324-325; H. C. LEA, op.cit., pp. 746-747.

107. AHN, Inq., libro 332, f. 14. Madrid, 31 de agosto de 1606. El consejo de la Suprema al Santo Oficio romano.

108. Ibidem. Madrid, 31 de agosto de 1606. El consejo de la Suprema a los inquisidores de Zaragoza.

109. O eso se intuye de un índice de las principales cuestiones inquisitoriales: BAV, Borgiano Latino, vol. 558, f. 1v. "Fugientes a carceribus SO Hispaniae at Portugaliae et comparentes ad hoc SO tractabuntur uti fugitive alii vero uti recurrentes ad sedem Apostolicam 11 maii 1606 [...]. Et primi remittuntur in Hispaniam, prima junii 1606. [...] Unus ex dictis fugitis fuit de ordine Sanctissimi consignatus hic Oratori Regis ut illum mitteret Inquisitoribus, qui vero fugiunt ante carceratione non remittuntur, 6 julii 1606".

110. AHN, Inq., libro 332, f. 15r. Madrid, 2 de septiembre de 1606. El consejo de la Suprema al Santo Oficio romano. 
Actitud opuesta se detecta en los dos últimos casos de fugitivos, que sorprende todavía más porque se trata en la misma misiva de la Suprema a los subordinados zaragozanos. Adam Cacimet, de Sástago, es sponte el 29 de marzo en Roma ${ }^{111}$. Esta vez el Santo Oficio romano no le otorga la absolución, sino que devuelve al morisco a los inquisidores de Aragón acompañándolo por una cédula comendaticia del cardenal Antonio Zapata ${ }^{112}$, que hace poco ha entrado a formar parte de la Sacra Congregación de la $\mathrm{Fe}^{113}$. El escrito del alto prelado español, en nombre de Pablo V, serviría para hacer llegar a la Suprema la postura de Roma sin tener que recurrir a una vía diplomática más oficial que, con toda su violencia, desautorizaría a la institución ibérica ante la minoría morisca. La recomendación papal se ejecuta con Adam: además de recibir el trato benigno y blando "en lo que toca a la causa de fe", Adam no sería encausado por la posesión de armas, pasando por encima un aspecto que en esa época goza de cierta relevancia. En cambio, en Madrid no sienta bien lo acontecido con Juan de Almaedí de Calanda, contra el cual se planifica la detención al regresar de Roma "por aver traído armas". Esta vez el vicario general capitolino lo había absuelto in utroque foro. Para hacerse con Juan, sorteando la decisión romana, el inquisidor general manda a los ministros zaragozanos aplicar el "edicto de las armas publicado contra los moriscos que los traxeran" ${ }^{114}$. La orden debe cumplirse "así, sin dar a entender tenéis orden nuestra"115 para finalmente escarmentar al morisco ${ }^{116}$. Podemos suponer que este Juan sea el Giovanni Macchi de Calanda reconciliado en 1603 en Roma ${ }^{117}$. Ante el vicario capitolino éste había confesado la posesión de una escopeta en casa, revelando asimismo el soborno de un oficial del centro penitenciario zaragozano para asegurarse el buen trato hacia otros moriscos detenidos que debían haberse sometido al tormento ${ }^{118}$. Reconciliado en forma en Italia, se ha dicho que se procede a su castigo en Zaragoza. Roma, una vez más, es ignorada y desafiada. Pero no se trata de un caso aislado.

Por aludir a otros ejemplos: Ana Arévalo, de Trasmoz, reconciliada el 12 de marzo de 1607 en Roma ${ }^{119}$, es llevada al auto de fe celebrado en Zaragoza el 29

111. ACDF, Decreta 1606, c. $96 \mathrm{rv}$.

112. ACDF, Decreta 1606, cc. 126v-127r. Roma, 19 de julio de 1606.

113. Su admisión en la Congregación deja su huella en los decreta: ACDF, Decreta 1606, c. 17v. Roma, 27 de enero de 1606.

114. AHN, Inq., libro 332, f. 2v. Madrid, 14 de julio de 1606. El consejo de la Suprema a la Inquisición de Zaragoza.

115. Ibidem.

116. AHN, Inq., libro 332, f. 33.

117. Macchi es casi seguramente la italianización de al-Macdí, el Almaedí de las fuentes inquisitoriales españolas.

118. "Hai tenuto un scoppietto in casa et dato la mancia al boia del SO acció trattasse bene detti tuoi fratelli che doveano esser tormentati in detto Santo Officio". TCD, ms. 1228, ff. 148r-150v. Sentencia del 31 de julio de 1610, abjuración de formali el día siguiente. Véase también ACDF, Decreta 1603, cc. $169 \mathrm{v}$ (primera deposición, 23 de julio) y 180v (segunda y sentencia, 31 de julio).

119. TCD, ms. 1229, ff. 78r-80v. ACDF, Decreta 1606, cc. 265v-266r. 
de octubre de 1608, junto a otras 28 mujeres moriscas, y condenada a cien azotes, a 20 ducados de multa y a la cárcel perpetua. Muere en las secretas y es reconciliada en estatua ${ }^{120}$. En el mismo auto de Ana, el rico mercader Juan de Granada, de Ambel, que abjura en marzo de 1607 en la ciudad de Pedro ${ }^{121}$, sufre en Zaragoza una sentencia de azotes y cárcel perpetua ${ }^{122}$. El culto Juan Vivas, de Torrellas, perdonado por Paulo V en $1607^{123}$, a pesar de haber admitido las acusaciones ante el inquisidor aragonés -las mismas por las que está imputado por la Congregación de la $\mathrm{Fe}-$-, es condenado a diez años de galeras y a la cárcel perpetua en noviembre de $1609^{124}$. Juan de Portugal, natural de Agreda y vecino de Aranda, "fue mandado prender [...] y auséntose y se va a Roma adonde confesó haber vivido como moro y fue absuelto de su apostasía debajo de condición cum clausula [...] a 22 de noviembre de 1607"125. En la tercera testificación en Zaragoza, Juan de Portugal "confesó haber escrito las cartas de muertos" y por ello es condenado a cuatro años de remo y cárcel perpetua. Lope Alax de Fréscano, sponte ante la congregación de la Fe en noviembre de $1607^{126}$, a pesar de delatar los nombres de otros varios moriscos desde Roma -donde se le había absuelto-, es quemado en la hoguera entre otras cosas por comprar un libro moriego a un copista de Aranda ${ }^{127}$. Por ironía del destino, estos perseguidos sufren sus condenas pocos años antes, o incluso meses, de la expulsión general. "Mejor" suerte tiene Juan de Burgo alias Amador Serrano, de Torrellas, quién en marzo de 1608 pide misericordia a Paulo $\mathrm{V}^{128}$. Mientras que la Suprema está investigando sobre su persona ${ }^{129}$, la congregación romana opta por aplazar la resolución de su causa $^{130}$. Todavía a la altura de abril de 1609 se discute sobre su caso ${ }^{131}$. No sa-

120. M. C. ANsón, Torrellas..., p. 235.

121. TCD, ms. 1229, ff. 70r-72v. ACDF, Decreta 1606, cc. 265v-266r. Juan se presenta con el hijo que no padece ninguna penitencia ("ut nihil fiat". Ibidem).

122. M. C. ANSÓN, Torrellas..., p. 234.

123. TCD, ms. 1229, ff. 447r-449v. ACDF, Decreta 1607, c. 437rv.

124. M. C. Ansón, Torrellas..., p. 269.

125. Relación de causa contra Juan de Portugal publicada en J. FouRNEL-GuÉRIN, "Le livre et la civilisation écrite", p. 257. Su sentencia y abjuración en Roma en TCD, ms. 1229, ff. 427r-429v; ACDF, Decreta 1607, c. 437rv.

126. ACDF, Decreta 1607 , c. 438 r.

127. Lope Alax, alias Soldado, que "representaría el elemento más recalcitrante a la asimilación, con todo aceptó la ayuda de los 'frailes descalzos que le ayudaron a morir'": J. MAIsO GONZÁLEZ, R. M. BlAsco MARTíneZ, "Frescano, 1583-1655. Una población morisca a través de los registros parroquiales", Estudios del Departamento de Historia Moderna, 1980-81, p. 78; J. FouRNEL-GUÉRIN, "Le livre et la civilisation écrite", p. 248.

128. ACDF, Decreta 1608 , c. 143. Roma, 21 de marzo de 1608.

129. M. C. ANSÓN, Torrellas..., p. 268.

130. ACDF, Decreta 1608, c. 265. Roma, 25 de junio de 1608. El 22 de diciembre del mismo año volvió a testificar (c. 540).

131. ACDF, Decreta 1609, c. 130. Roma, 1 de abril de 1609. 
bemos nada de su trayectoria en los años posteriores, si regresa a Aragón o se queda en la ciudad pontificia hasta que los congregantes deliberaran algo. Lo cierto es que en junio de 1613 está preso en las cárceles del Santo Oficio romano, sometido a tormento, finalmente castigado a los trirremes de Civitavecchia y juzgado como "inhabilis ad recipiendum Sacramentum eucharistiae"132.

\section{CONCLUSIONES}

Entonces, ¿por qué los moriscos aragoneses siguieron presentándose en Roma? "De hecho", arguye Lea, en Madrid las apelaciones se consideran "como nulas y sin valor. Resulta verdaderamente curioso que al cabo de tan larga experiencia aún encontrase la curia compradores lo bastante crédulos para buscar protección en ella. [...] tales absoluciones fueron recibidas con desprecio, y los reos fueron reconciliados con las mismas penas que sus compañeros" ${ }^{\prime 133}$.

A esta observación se contesta él mismo más adelante: a veces la Suprema decide escuchar las sentencias papales, pues es "preferible dejar a un presunto culpable en libertad antes que permitirle al Santo Oficio romano ejercer su jurisdicción" ${ }^{\prime 134}$. Algunos adinerados moriscos aragoneses prefieren arriesgar un largo viaje que dejar su destino totalmente en manos de los tribunales españoles que, a la sazón, llevan a cabo la represión más despiadada de su historia institucional contra esa minoría ${ }^{135}$.

Una última reflexión lleva a plantear una pregunta trascendente: ¿por qué estos moriscos huidos de España, en lugar de ir a Berbería o a Estambul, van a Roma con ánimo de regresar a España? No estoy seguro de tener la respuesta: se puede cuestionar la sincera cristiandad de estos individuos, pero su firme intención es vivir en su casa. Aunque no deja de ser paradójico, los moriscos recurren a la máxima figura religiosa de la cristiandad -el papa-y por su mismo pragmatismo la religión pasa a un segundo plano.

132. ACDF, Decreta 1613, cc. 275-276. Roma, 13 de junio de 1613. Véase también cc. 213-124 (15 de mayo).

133. H. C. LEA, op.cit., p. 748.

134. Ibidem, p. 749.

135. En el lapso 1606-10, en el reino de Aragón el 84,8\% de perseguidos es morisco: Procesados por la Inquisición según las relaciones de causas en R. BENíteZ, op.cit., p. 733. 


\title{
RESUMEN
}

La historiografía puede contar con unas pocas aportaciones sobre la vertiente de la diáspora morisca en Italia tras su destierro de la Península ibérica (1609-14), mientras que carecen del todo los estudios sobre los contactos entre los moriscos e Italia previos a la expulsión general. A principios del siglo XVII, una nueva oleada represiva afectaba a la comunidad morisca en los territorios de la Monarquía. Con esta aportación me propongo referir y contextualizar la fuga a Roma de un grupo de moriscos aragoneses, afectados por los rumores de denuncias que corrían a su cargo ante los Inquisidores españoles. Con el objetivo de llegar a la ciudad del papa, los moriscos se autodenunciarían ante el Santo Oficio romano con la esperanza de obtener un trato más benévolo que el esperado en sus patrias. De ese modo, estos individuos podían volver a sus territorios de origen exhibiendo los documentos de absolución que el Pontífice, a través del Tribunal inquisitorial romano, les había otorgado, beneficiándose de facto de una situación de inmunidad. Con el propósito de comentar estas ocurrencias:-describiré el perfil de estos moriscos imputados en Roma-; pondré de manifiesto los conflictos jurisdiccionales surgidos entre el Santo Oficio romano y español, a raíz de las sentencias de absolución expedidas por el primero en favor de estos perseguidos.

Palabras clave: moriscos aragoneses, Suprema, Santo Oficio romano, conflictos jurisdiccionales, absolución papal, salvaguarda.

\begin{abstract}
Historiography counts with few contributions about the Morisco diaspora in Italy after its expulsion from the Iberian Peninsula (1609-14); however any study on contacts between the Morisco and Italy prior to the general expulsión has been done. The aim of this contribution is to report and contextualize the escape to Rome of a group of Aragonese Moriscos, affected by rumors of denunciations against them before the Spanish Inquisitors. In order to reach the city of the Pope, the Moriscos denounced themselves before the Holy Office with the hope of obtaining a treatment more benevolent than in their homeland. Thereby these individuals could return to their original territories displaying the documents of absolution that the Pontifex gave them through the Roman Inquisitorial Tribunal, taking profit of a situation of immunity. Analyzing these facts I will describe the profile of these Moriscos imputed jurisdictional conflicts that arose between the Holy Office of Rome and that of Spain, following the verdicts of absolution issued by the first in favor of those persecuted.
\end{abstract}

Key words: Aragonese Moors, Spanish Inquisition, Roman Holy Office, conflicts of jurisdiction, papal absolution, safeguard. 